\title{
KINETIC STUDY OF BIOSORPTION OF ARSENIC FROM SOIL USING MICROORGANISMS
}

\author{
E. Atikpo ${ }^{1,}{ }^{*}$, J. E. Agori ${ }^{2}$, M. T. Peretomode ${ }^{3}$, A. Micheal ${ }^{4}$ and E. C. Ofonedu ${ }^{5}$ \\ 1, 2, Department of Civil Engineering, Faculty of Engineering, Delta State University, Oleh Campus, \\ PMB 1, ABRAKa, DelTA StaTe, NIGERIA. \\ 3, Department of Chemical Engineering, Faculty of Engineering, Delta State University, Oleh Campus, \\ PMB 1, ABRAKA, DELTA STATE, NIGERIA.

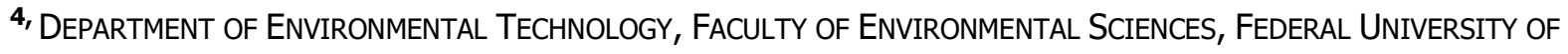 \\ TECHNOLOGY, OWERRI, PMB 1526, IMO STATE. \\ 5, Department of EnVironmental Science And Resource Management, FaCulty of SCIENCE, National \\ Open UniVersity of Nigeria, UniVersity VilLAGE, PLOt 91, CADESTRAL Zone, \\ NNAmdi AZIKIWE Way, JABI, ABUJA, NIGERIA. (BENIn Study CENTER) \\ E-mail addresses: ${ }^{1}$ eatikpo@delsu.edu.ng, ${ }^{2}$ agorije@delsu.edu.ng, ${ }^{3}$ tekenapereto@gmail.com, \\ 4 mimimichaels@gmail.com, 5 emmajesus94@gmail.com
}

\begin{abstract}
This work studied the kinetics of biosorption of arsenic (As) from polluted soils using two bacteria [Proteus mirabilis (P. mirabilis) and Bacillus subtilis (B. subtilis)]. The bacteria obtained from the soils were cultured and utilized to treat the arsenic polluted soils through the process of batch biosorption experiment. The experimental data were fitted with four kinetic models (Pseudo-first order, pseuodo-second order, Elovich and the intra-particle diffusion); and judgement on models performance was made using the values of the models' coefficient of determination $\left(R^{2}\right)$. The four models tested were adequate for describing the biosorption kinetics but the leading performance of the intraparticle diffusion model with $R^{2}$ of 0.991 for sorption by $P$. mirabilis and 0.972 for sorption by $B$. subtilis proved the diffusion process to be the rate-limiting step. This indicated that the systems were transport controlled.
\end{abstract}

Keywords: Arsenic, contaminated soils, biosorption, sorption kinetics, microorganisms.

\section{INTRODUCTION}

Growth in industrial exploration of natural earth resources has triggered increased discharge and accumulation of heavy metals in environmental components; and these metals are injurious to these components $[1,2]$ as they bioaccumulate to become toxic to plants and animals' lives [3].

Though, some of these metals are useful to flora at adequate concentrations [2], arsenic being a principal environmental pollutant constitute environmental health problem for millions of humans on earth [4]. Almost every organ in human body is susceptible to arsenic exposure, with diverse health impacts including lung disease, skin lesions and cancer [5]. Chronic exposure to arsenic leads to inflammation of the conjunctiva membrane; vesicular rashes, skin pigmentation, hyperkeratosis, destruction of redblood cells, bone marrow depression, renal damage, irrational speech, poor memory, paralysis and degeneration of inner ear [6].

To make the ecosystem fit for man and other live sustaining organisms, polluted soils with heavy metals need to be corrected through treatment [1, 2]. Some microorganisms are suitable for correcting soil concentration of heavy metals. This Process is known as bioremediation $[1,7]$; and it is significantly

* Corresponding author, tel: $+234-803-866-5352$ 
considered for treating metals contaminated ecosystem [1].

Other convectional techniques of correcting metals contaminated soils exist, and are housed under physical and chemical techniques. They are effective for metals pollution control but are very expensive when heavy metals concentrations in soils are very low $[1,8]$.

This is why biological techniques have been under serious research. It is regarded as a sustainable remediation technology to correct and restore the natural state of soil [1,2]. Blaylock and others in [9] reported the cleaning cost minimization in bioremediation as they were able to save fifty to sixty-five percent of cost on applying bioremediation as a treatment alternative in one acre of leadcontaminated soil compared with excavation and landfill [10].

Therefore, this work focuses on bioremediation of arsenic polluted soils using two organisms: Proteus mirabilis and Bacillus subtilis isolated from the same soils obtained from the forest of Amaonye in Ishiagu communities in Ebonyi State, Nigeria. It focuses specifically on the kinetics of biosorption of this metal from the soils by engaging four mathematical kinetic models (Pseudo-first order model, pseuodo-second order model, Elovich model and the intra-particle diffusion model) to fit experimental data.

\section{MATERIALS AND METHODS}

\subsection{Materials}

These include soil samples, pipettes, beakers, conical flasks, microscope, Petris dishes, inoculating needles, cotton wool, atomic absorption spectrophotometer, measuring cylinders, wire loops, incubator, MacCartney bottles, refrigerator, autoclave, what man filter papers, hot plate and magnetic stirrer.

\subsection{Reagents and Nutrients}

These include Lugo's iodine, nitric acid, potato dextrose agar, perchloric acid, crystal violent, Simon citrate ager, hydrogen peroxide, ethanol, peptone water, methylene blue, sulphuric acids, triple sugar iron ager, oxidase reagent, hydrochloric acid, nutrient agar, sodium hydroxide, Kovac's reagent, safranin and MacConkery ager.

\subsection{Preparation of Nutrients}

In line with the manufacturers' stipulations and the methods in [11], the solutions of triple sugar iron agar, peptone water powder, nutrient agar, Simon
Citrate agar and MacConkey agar were prepared by measuring, soaking and swirling 65, 15, 28, 24 and 52 grams of powder of the respective nutrients in $1000 \mathrm{~cm}^{3}$ of distilled water for ten minutes. The respective solutions were autoclaved for 15 minutes at $121^{\circ} \mathrm{C}$ and 1.5 pounds per square inch (psi) and then cooled to $45^{\circ} \mathrm{C}$.

\subsection{Recognition of Organisms:}

Bacteriological study was conducted in microbiology laboratory on soil sample obtained from a forest in Amaonye - Ishiagu, Ebonyi State of Nigeria. The soil was serial diluted, and $0.1 \mathrm{ml}$ each from $10^{-1}$ of the serial dilution was inoculated into different sterile petri-dishes using pure plating approach $[12,13]$ and were incubated at temperature of $37^{\circ} \mathrm{C}$ for 24 hours [11]. The grown Colonies were enumerated, sub cultured and characterized using the techniques in $[11,14,15]$

\subsection{Optimum Factors Determination}

Heavy metals contaminated land remediation is optimally efficient when it is conducted at the optimum values of factors enhancing remediation. Experimental screening of these factors is a prerequisite to their optimal selection. The factors considered are nutrient dosage $(\mathrm{ml})$, organisms' weights $(\mathrm{g}), \mathrm{pH}$, temperature $\left({ }^{\circ} \mathrm{C}\right)$ and stirring frequency [per week (pw)]. The screening was conducted in batches and in triplicate $[16,17]$.

Nutrient dosage of 1, 2, 3, 4, 5, 6 and $7 \mathrm{ml}$ were measured into twenty-one (21) identical $50 \mathrm{ml}$ beakers, containing $4 \mathrm{~g}$ of soil samples each. The soils were inoculated with respective 24 days old bacterium; and evaluated to determine the residual arsenic ion on the $21^{\text {st }}$ day with Atomic Absorption Spectrophotometer (GBC Sens AA, Model no. A6358) after deleting the bacterial from samples through the use of centrifuge [17].

The process was adopted to screen the optimum values of factors from varied values of $1,2,3,4,5$, 6 , and $7 \mathrm{~g} ; 20,25,30,35,40$ and $45^{\circ} \mathrm{C} ; 4,5,6,7,8$, 9 and 10; and $0,1,2,3,4,5$ and 6 per week (pw) of organisms' masses; weights; temperature; $\mathrm{pH}$; and stirring frequency per week respectively.

\subsection{Biosorption and Kinetics}

Four (4) grams of soils each were inoculated respectively with the bacterium in thirty $50 \mathrm{ml}$ beakers (fifteen for each bacterium) and conditioned with the optimized values of $\mathrm{pH}$, temperature $\left({ }^{\circ} \mathrm{C}\right)$, organisms' 
weights ( $\mathrm{g})$, stirring frequency (pw) and nutrient dosage $(\mathrm{ml})$ of $7,30^{\circ} \mathrm{C}, 1 \mathrm{~g}, 6 \mathrm{pw}$ and $8 \mathrm{ml}$ for Proteus mirabilis; and $8,30^{\circ} \mathrm{C}, 5 \mathrm{~g}, 6 \mathrm{pw}$ and $8 \mathrm{ml}$ for Bacillus subtilis.

The residual As ion in soil was determined with Atomic Absorption Spectrophotometer (GBC SensAA, Model no. A6358) in triplicate $[16,18]$ at times 7,14 , 21,28 and 35 days after centrifuging the soil samples to eliminate the organisms $[17,18]$.

The ions removed with time and at equilibrium in $\mathrm{mg} / \mathrm{kg}$ were determined from Equations (1) and (2) $[19,20]$.

$$
\begin{aligned}
& \mathrm{q}_{\mathrm{t}}=\frac{\left(C_{o}-C_{t}\right)}{m} \cdot V \\
& \mathrm{q}_{\mathrm{e}}=\frac{\left(C_{o}-C_{e}\right)}{m} \cdot V
\end{aligned}
$$

$C_{0}, C_{t}, C_{e}, q_{t}, q_{e}, V$ and $m$ are the initial, residual, equilibrium ions in $\mathrm{mg} / \mathrm{kg}$ present in soil; amount removed with time, amount removed at equilibrium in $\mathrm{mg} / \mathrm{kg}$; volume $\left(\mathrm{m}^{3}\right)$ of soil used and the mass $(\mathrm{g})$ of organisms put in contact with the bacteria [17]. The experimental data was fitted with pseudo-first order, pseudo-second order, simple Elovich and intraparticle diffusion models to evaluate the kinetics of the metal ion biosorption from the soils.

\section{RESULTS AND DISCUSSION}

\subsection{Microbiology Analysis}

Microbial analysis conducted for characterizing the organisms produced the requisite bacteria from the developed colonies of $2.5 \times 10^{2} \mathrm{cfu} / \mathrm{ml}$. The organisms were recognized with the various biochemical tests. B. subtilis shown gram positive rods (GPR) in gram stain and positive catalase, positive oxidase, negative indole, negative citrate, positive glucose, positive lactose, negative $\mathrm{H}_{2} \mathrm{~S}$ and positive motility. $\mathrm{P}$. mirabilis shown gram negative rods (GNR) in gram stain, and positive catalase, negative oxidase, negative indole, negative citrate, positive glucose, positive lactose, positive $\mathrm{H}_{2} \mathrm{~S}$ and positive motility.

\subsection{Optimum Factors}

The varied values of $1,2,3,4,5,6$ and $7 \mathrm{ml} ; 1,2,3$, 4, 5, 6 and $7 \mathrm{~g} ; 20,25,30,35,40$ and $45^{\circ} \mathrm{C} ; 3,4,5$, $6,7,8,9$ and 10; and 0, 1, 2, 3, 4, 5 and 6 per week (pw) of Nutrient dosage, organisms' weights, temperature, $\mathrm{pH}$ and stirring frequency per week respectively yielded the optimum values of $\mathrm{pH}$, temperature $\left({ }^{\circ} \mathrm{C}\right)$, organisms' weights $(\mathrm{g})$, stirring frequency $(\mathrm{pw})$ and nutrient dosage $(\mathrm{ml})$ of $7,30^{\circ} \mathrm{C}$,
$1 \mathrm{~g}, 6 \mathrm{pw}$ and $8 \mathrm{ml}$ for Proteus mirabilis; and $8,30^{\circ} \mathrm{C}$, $5 \mathrm{~g}, 6 \mathrm{pw}$ and $8 \mathrm{ml}$ for Bacillus subtilis.

\subsection{Pseudo-First Order Model}

Pseudo first order equation generally expressed as given in equation (3) was linearized. The model parameter $\mathrm{q}_{\mathrm{e}}$ is the sorption capacity at equilibrium $\left(\mathrm{mg}^{\mathrm{kg}} \mathrm{g}^{-1}\right) ; \mathrm{q}_{\mathrm{t}}$ is the sorption capacity at time $\mathrm{t}$ $\left(\mathrm{mg}^{\mathrm{kg}} \mathrm{g}^{-1}\right)$; and $\mathrm{k}$ is the rate constant of pseudo first order adsorption $\left(\mathrm{d}^{-1}\right)$.

$$
\frac{d q_{t}}{d t}=k\left(q_{e}-q_{t}\right)
$$

The linear fits between $\ln \left(q_{e}-q_{t}\right)$ and $t$ for the ion removal was obtained as shown in Figure 1 showing the regression equations and the coefficients of determination, $\mathrm{R}^{2}$. The models' parameters, $\mathrm{K}$ and $\mathrm{q}_{\mathrm{e}}$ deduced from the fit are $-0.085 d^{-1}$ and 0.0385 for Bacillus subtilis; $-0.097 \mathrm{~d}^{-1}$ and 0.1084 for Proteus mirabilis. The very high $R^{2}$ values of the models indicated that batched experimental data can be described by pseudo-first-order kinetic models.

The model showed a better fit for removal by Bacillus subtilis than Proteus mirabilis. This was ascertained from their $\mathrm{R}^{2}$ of 0.965 for Bacillus subtilis and 0.933 for Proteus mirabilis. The order of ion removal by the organisms as depicted by the $\mathrm{K}$ values of $-0.085 \mathrm{~d}^{-}$ ${ }^{1}$ and $-0.097 d^{-1}$ is B. Subtilis before P. mirabilis.

\subsection{Pseudo-Second Order Model}

The pseudo second order kinetic equation expressed by [21] and presented in equation (4) was linearized. The parameter, $\mathrm{q}_{\mathrm{e}}$ is the sorption capacity at equilibrium $\left(\mathrm{mg}^{\mathrm{kg}} \mathrm{g}^{-1}\right) ; \mathrm{q}_{\mathrm{t}}$ is the sorption capacity at time $\mathrm{t}$ in $\mathrm{mg}^{\mathrm{kg}}{ }^{-1}$; and $\mathrm{k}_{1}$ is the rate constant of pseudo second order sorption in $\mathrm{kg} . \mathrm{mg}^{-1} \mathrm{~d}^{-1}$.

$$
\frac{d q_{t}}{d t}=k_{1}\left(q_{e}-q_{t}\right)^{2}
$$

The linear fits between $t / q_{t}$ versus $t$ for the ion was obtained and shown in Figure 2 bearing the regression equations and the coefficients of determination, $\mathrm{R}^{2}$ while models' parameters, $\mathrm{K}_{1}$, $\mathrm{q}_{\mathrm{e}}$ and $h_{0}$ were calculated.

The very high $\mathrm{R}^{2}$ values of 0.955 and 0.894 of the model for arsenic ion removal by Proteus mirabilis and bacillus subtilis respectively showed very good correlation, and indicated that the batched experimental data can be described by pseudosecond-order kinetic model.

The order of removal of the ion as described by $K_{1}$ values is Bacillus subtilis before Proteus mirabilis. 
These $K_{1}$ values were derived to be $0.7437 \mathrm{~kg} / \mathrm{mg} . \mathrm{d}$ and $0.2002 \mathrm{~kg} / \mathrm{mg}$.d respectively. This is an indication that the removal capacity of Bacillus subtilis exceeded that of Proteus mirabilis. The $h_{0}$ values were calculated to be $0.0016 \mathrm{mg} \cdot \mathrm{kg}^{-1} \cdot \mathrm{d}^{-1}$ and 0.0032 $\mathrm{mg} \cdot \mathrm{kg}^{-1} \cdot \mathrm{d}^{-1}$ for $\mathrm{B}$. subtilis and $\mathrm{P}$. mirabilis respectively.

\subsection{Elovich Model}

The Elovich equation expressed in [22] and presented in equation (5) was linearized and employed to fit experimented data. The parameter $\alpha$ is the initial sorption rate in $\mathrm{mg}^{-1} \mathrm{~kg}^{-1}$; and $\beta$ is desorption rate constant $\mathrm{mg} \cdot \mathrm{kg}^{-1} \mathrm{~d}^{-1}$.

$$
\frac{d q_{t}}{d t}=\alpha \exp \left(-\beta q_{t}\right)
$$

The linear relationship fits between $q_{t}$ versus $\ln (t)$ for arsenic ions biosorption using the selected microorganisms are shown in Figures 3. This displayed the regression equations and the coefficients of determination $R^{2}$, while the values of models parameters $\alpha$ and $\beta$ were derived to be $0.0037 \mathrm{mg} \cdot \mathrm{kg}^{-1}$ and $100.00 \mathrm{mg} \cdot \mathrm{kg}^{-1} \mathrm{~d}^{-1}$ for B. subtilis; $0.0072 \mathrm{mg} \cdot \mathrm{kg}^{-1}$ and $40.000 \mathrm{mg} \cdot \mathrm{kg}^{-1} \mathrm{~d}^{-1}$ for $P$. mirabilis respectively.

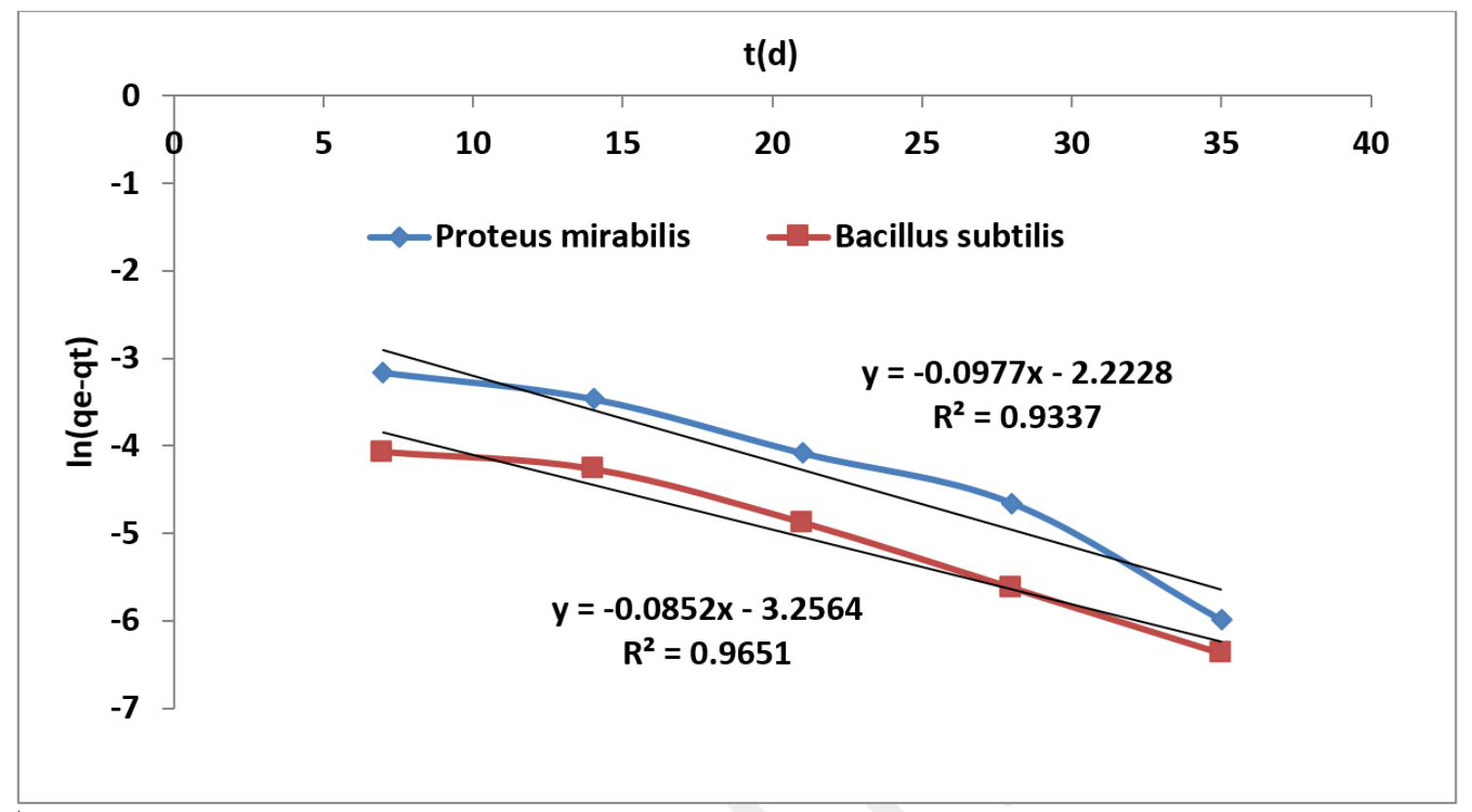

Figure 1: Fitting of Pseudo-First Order Model

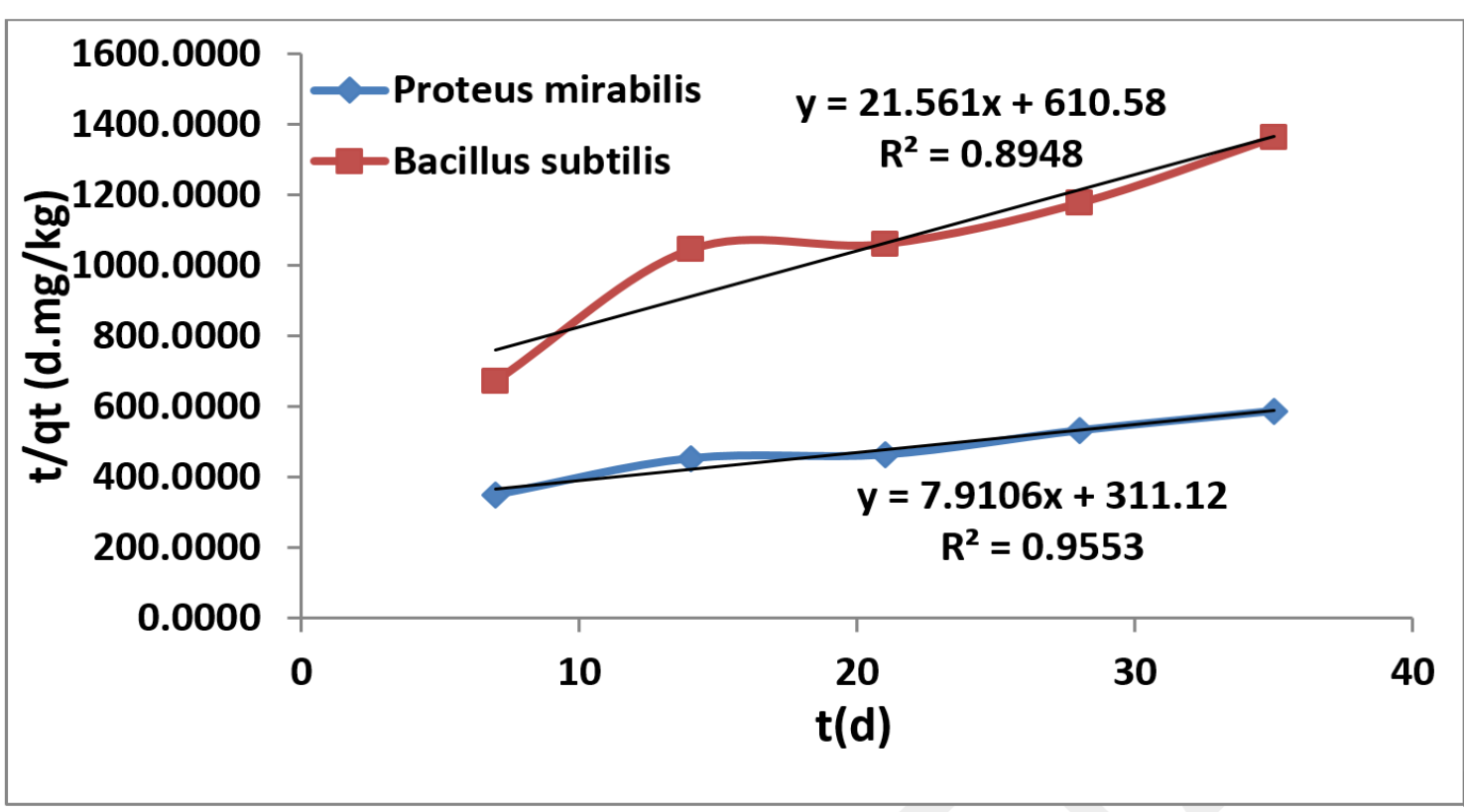

Figure 2: Fitting of Pseudo-Second Order Model 
The very high $\mathrm{R}^{2}$ values of 0.975 and 0.944 of the models for arsenic removal by Proteus mirabilis and Bacillus substilis respectively showed very good correlation, and indicated that the experimental data can be described with Elovich model.

\subsection{Intra-particle Diffusion Model}

According to [23], intra-particle diffusion model is expressed as presented in equation (6). The model was linearized and used in fitting the experimental data on arsenic removal by the organisms employed. The parameter $X$ is the boundary layer diffusion effects; $K_{2}$ is the rate constant for intra-particle diffusion.

$$
q_{t}=K_{2} t^{\frac{1}{2}}+X
$$

The linear relationship fits between $q_{t}$ and $t^{1 / 2}$ for arsenic ions biosorption using the selected organisms are shown in Figures 4 displaying regression equations and the coefficients of determination, $R^{2}$. The sorption capacity $\mathrm{K}_{2}$ was corresponded to the slope. The very high $\mathrm{R}^{2}$ values of the models showed very good correlation, indicating that batched experimental data can be described by intra-particle diffusion kinetic model.

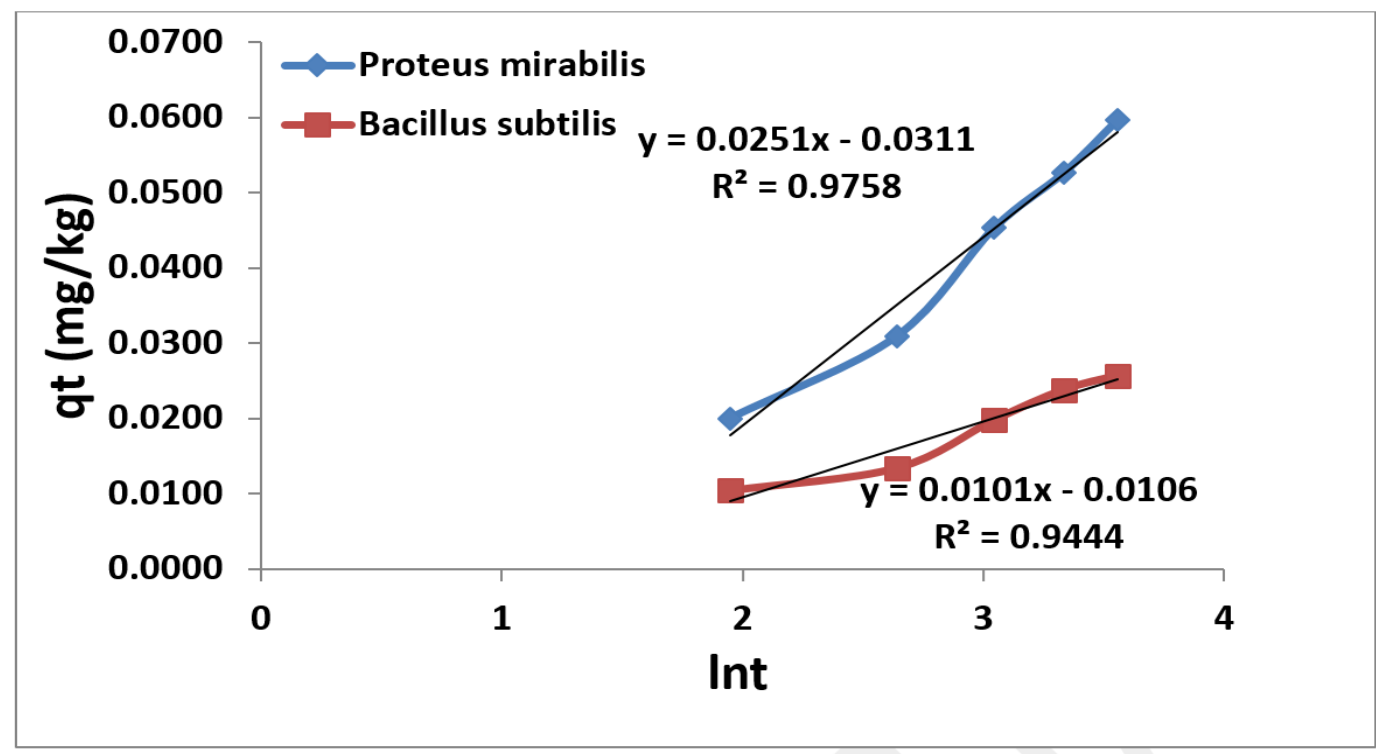

Figure 3: Fitting of Elovich Model

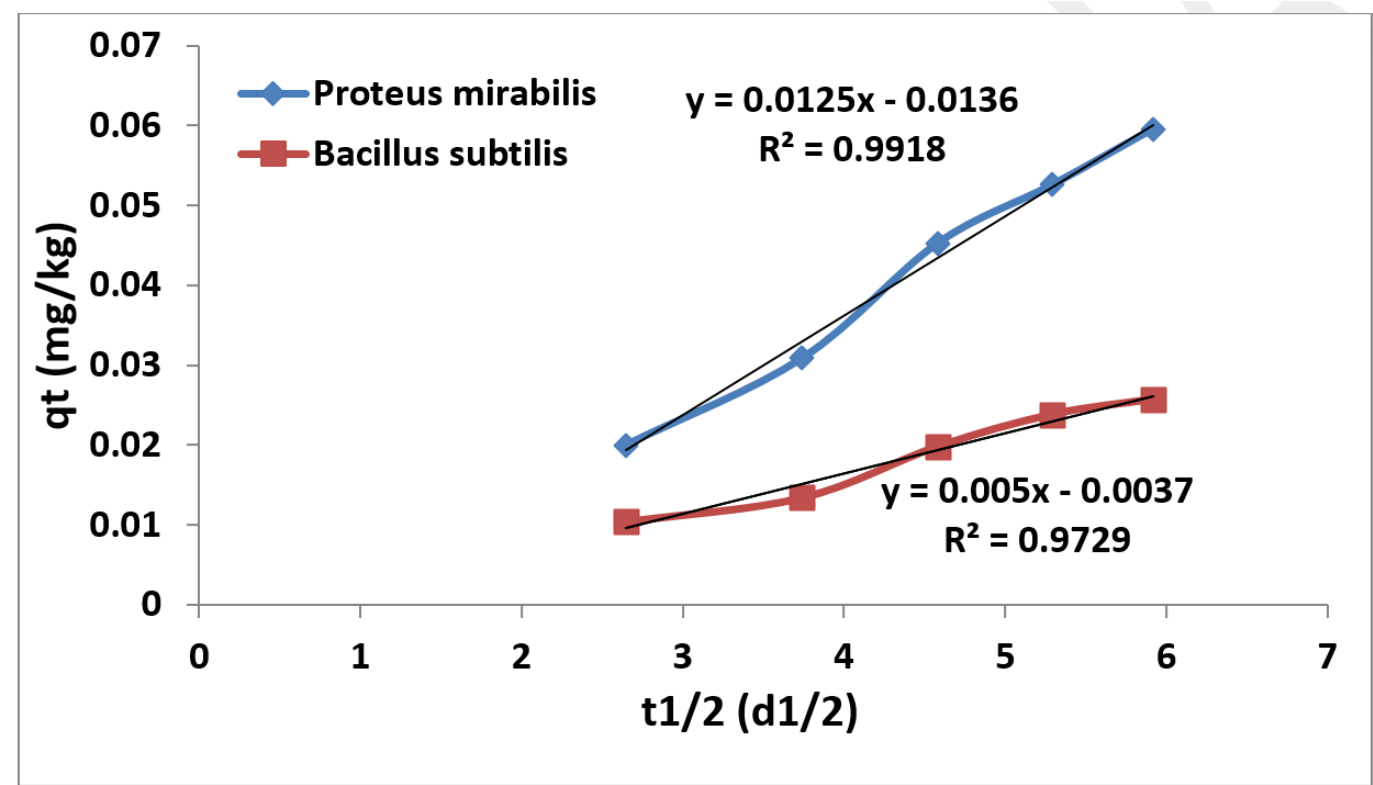

Figure 4: Fitting of Intra-particle Diffusion Model 
Table 1: Comparison of Coefficient of Determination

\begin{tabular}{ccccc}
\hline & \multicolumn{3}{c}{ Coefficient of Determination $\left(R^{2}\right)$} \\
\cline { 2 - 5 } Microorganisms & Pseudo-Second Order & Pseudo-First Order & Elovich & Intra-particle Diffusion \\
& Model & Model & Model & Model \\
\hline Proteus mirabilis & 0.933 & 0.955 & 0.975 & 0.991 \\
Bacillus subtilis & 0.965 & 0.894 & 0.944 & 0.972 \\
\hline
\end{tabular}

The order of fit as deduced from $R^{2}$ values is 0.991 for Proteus mirabilis and 0.972 for Bacillus subtilis. The order of sorption capacity as deduced from $\mathrm{K}_{2}$ values was also Proteus mirabilis with a value of 0.009 $\mathrm{mg} / \mathrm{kg} \cdot \mathrm{d}^{1 / 2}$ and Bacillus substilis with a value of 0.005 $\mathrm{mg} / \mathrm{kg}^{\mathrm{d}} \mathrm{d}^{1 / 2}$.

Based on the respective models' $\mathrm{R}^{2}$ values, the four models gave very good fit for arsenic sorption by the organisms. But from the comparison in Table 1, it was discovered that the intra-particle diffusion model gave the best fit with $\mathrm{R}^{2}$ of 0.991 for sorption by $\mathrm{P}$. mirabilis and 0.972 for sorption by $B$. subtilis. This indicated that the diffusion process was the rate-limiting step and the systems were transport controlled.

\section{CONCLUSION}

This work has studied the kinetics of arsenic biosorption by Proteus mirabilis and Bacillus subtilis. It focused on testing the suitability of existing kinetic models in describing the control process of As ion biosorption from contaminated soils.

The four models tested were adequate in describing the sorption kinetics but the extra performance of the intra-particle diffusion model proved the diffusion process to be the rate-limiting step. This indicated that the systems were transport controlled.

\section{REFERENCES}

[1] Girma, G. "Microbial Bioremediation of Some Heavy Metals in Soils: An Updated Review". Indian J. Sci. Res. Vol. 6, No. 1, 2015, pp 147-161.

[2] Dixit, R.., Wasiullah, Malaviya, D., Pandiyan, K., Sinhg, U.B., Sahu, A., Shukla, R., Singh, B. P., Rai, J. P., Sharma, P. K., Lade, H., Paul, D. "Bioremediation of Heavy metals from Soil and Aquatic Environment: An Overview of principles and Criteria of Fundamental Processes". Sustainabi. Vol. 7, 2015, pp 2189-2212.

[3] Sabale1, S. R., Tamhankar, B. V., Dongare, M. M., Mohite, B. S. "Extraction, Determination and Bioremediation of Heavy Metal Ions and Pesticide Residues from Lake Water" .J. Bioremedi. Biodegra. Vol. 3, No.4, 2012, pp 2155-6199.
[4] World Health Organization. "Guidelines for Drinking-Water Quality: Incorporating 1st and 2nd Addenda Recommendations". Third edition, Vol. 1, 2008.

[5] Naujokas, M. F., Anderson, B., Ahsan, H., Aposhian, H. V., Graziano, J. H., Thompson, C., Suk, W.A.2013. "The Broad Scope of Health Effects from Chronic Arsenic Exposure: Update on a Worldwide Public Health Problem". Environ. Heal. Perspec., Vol.121,2013, pp 295-302.

[6] Athar, M., Vohora, S. B. "Heavy Metals and Environment". New Age International (P) Limited Publishers, 4835/24, Ansari Road, Daryaganji, New Delhi-110002, 2006.

[7] Kulshreshtha1, A., Agrawal, R., Barar, M., Saxena, S. "A Review on Bioremediation of Heavy Metals in Contaminated Water" .J. Environm. Sci. Toxico. Foo. Techno. Vol. 8, Issue 7, 2014, pp 44-50.

[8] Bahi, J. S., Radziah, O., Samsuri, A. W., Aminudin, H. Fardin, S. "Bioleaching of Heavy Metals from Mine Tailings by Aspergillus fumigatus". Bioremed. J. Vol.16, 2012,pp 57-65.

[9] Blaylock, M. J., Salt, D.E., Dushenkov, S., Zakharova, O., Gussman, C., Kapulnik, Y., Ensley, B.D., Raskin, I. "Enhanced Accumulation of $\mathrm{Pb}$ in Indian Mustard by Soil-Applied Chelating Agents". Environ. Sci. Technol. Vol. 31, 1997, pp 860-865.

[10] Chibuike, G., Obiora, S. "Heavy Metal Polluted Soils: Effect on Plants and Bioremediation Methods". Appl. Environ. Soi. Sci., 2014.

[11] Chessebrough, M. "District Laboratory Practice in Tropical Countries". Part 2, Cambridge Low Price Edition, Cambridge University Press, London, 2000.

[12] Cowan, S. T. "Cowan and Steels Manual for the Identification of Medical Bacteria". Cambridge University Press, London, 1993.

[13] Baron, E. J., Peterson, L. R. Finegold, S. M. "Bailey and Scotts Diagnostic Microbiology". $9^{\text {th }}$ Edition, Mosby, Baltimore, 1994.

[14] Cowan, S. T. Steel, R. "Manual for the Identification of Medical Bacteria". Cambridge University Press, London, 1990. 
[15] Holt, J. C. "The Shorter Bergeys Manual of Determinative Bacteriology". Eight Edition, Williams and Willkins Company, Baltimore, 1994.

[16] Lima, E. C., Royer, B., Vaghetti, J. C. P., Brasil, J. L., Simon, N. M., Dos, S. Jr. A. A., Pavan, F. A., Dias, S. L. P., Benvenutti, E. V., Da Silva, E. A. "Adsorption of Cu (II) on Araucaria Angustifolia wastes: Determination of the Optimal Conditions by Statistic Design of Experiments". J. Hazar. Mate. Vol.140, 2007, pp 211-220.

[17] Atikpo, E., Michael, A. "Performance Evaluation of Six Microorganisms Ultilized for the Treatment of Lead Contaminated Agricultural Soil". J. Appl. Sci. Environ. Manage. Vol. 22, No. 7, 2018, pp 1105-1109.

[18] Atikpo, E. "Spatial Distribution and Attenuation of Heavy Metals Pollution in Amaonye Ishiagu Forest Soils". A PhD Thesis Submitted to the Department of Civil Engineering, University of Benin, Benin City, Nigeria, 2016.
[19] Badmus, M. A. O., Audu, T. O. K., Anyata, B. U. "Removal of Lead Ion from Industrial Wastewaters by Activated Carbon Prepared from Periwinkle Shells (Typanotonusfuscatus)". Turk. J. Envi. Engin. Sci. Vol. 31, 2007, pp 251263.

[20] Chen, H., Wang, A. "Kinetic and Isothermal Studies of Lead Ion Adsorption onto Palygorskite clay". J. Collo. Interf. Sci. Vol. 307, 2007, pp 309-316.

[21] Ho, Y. S., JohnWase, D. A., Forster, C. F. "Study of the Sorption of Divalent Metal Ions onto Peat". Adsorpti. Sci. Techno. Vol. 18, 2000, pp 639-650.

[22] Chien, S. H., Clayton, W. R. "Application of Elovich Equation to the Kinetics of Phosphate Release and Sorption on Soil". J. Soil Sci. Vol. 44, 1980, pp. 265-268.

[23] Mckay, G. Poots, V. J. "Kinetics and Diffusion Processes in Colour Removal from Effluent Using Wood as an Adsorbent". J. Chemic. Technol. Biotechno. Vol. 30, 1980, pp 279-292. 